одновременно острой малярией; последняя, несмотря на антисифилитическое лечение $($ ртуть $+\mathrm{Neo})$ не исчезла, а только изменила клиническое течение и вскоре дала рецидивы; кроме того, в двух случаях хронической малярии и сифилиса, одна инфекция не могла подавить другую. Автор считает, что плазмодии малярии и бледные спирохэты могут ужкваться в одном организме - и поэтому берет под сомнение современную терапию прогресс. паралича и раннего сифилиса искусственными прививками малярии, придя, однако, в конце статьи к правильному выводу, что успех инфекционной терапии зависит не от инфекционной терапии как таковой, а от последующего лечения Neо. (Не нужно забывать и одной пользующейся известным признанием теории действия инфекционной терапии-это разрыхление гематоэнцефалического барьера для последующего введения Nео. Pe(h.).

A. Вайнитейн.

242. K вопросу о нахолсении spir. pallida в органах мьишей, зараженныю сияилисои. J a h n el u. Prigg e (D. m. W № 17, 1929 г.), заражая мышей интраперитонеально птаммами $\mathrm{N}$ i cho Is, Truffi и M ulzev'a, подвергали впоследствии гистологическому исследованию ткани различных органов с целью обнаружить спирохэт. На основании свопх исследований а.а. приходят к выводам, что в лимфатических железах сифилитических мышей, у готорых инфекция протекала бессимптомно, удаетсл в фазах обнаружить sp. pallida, поиски же спирохэт в центральной нервной системе оказались безуспешными. Таким же образом удается обнаружить спирохэт и у кроликов в лимфатических железах, удаленных от склероза.

A. Д.иитриев.

243 Сияилис иентральной нервной системьь. Кричевский и Фр ид е (Kl. W, № 36, 1929 г.), заражая мышей кусочками панкров, содержащих большое количество sp. pallida, давали части животных с профилактической целью стоварсолан, предполагая тем самым предупредить заболевание центр. нерв. сшстемы. В результате своих наблюдений авторы отмечают, что зараженные sp. pal. мыши, кои получили стоварсолан, не заболевали сифилисом и их центральная нервная система в $100 \%$ случаев оставалась свободной от спирохэт.

\title{
A. Дмитриев.
}

244. Существуют ли спешанные бормь врожденного и приобретенного сияилиса у грудных детей? Е. Hoffmann (D. m. W, № 31, 1929 г.) указывает, что утверждение о возможности существования тех и др. форм сифилиса у грудных детей обосновано клиническими и экспериментальными исследованиями над суперинфекцией. Заразившийся до родов, но кажущийся здоровым грудной ребенок может во время родов или вскоре после них получить кожный шанкр (суперинфекция), который, сопровождаясь припуханием близлежащих желез, может симулировать чистый приобретенный сифилис. Подобная двойная инфекция представляется редкостью и ее можно, в понятии Тарновского „syphilis binaria“ взрослых, назвать каг syphilis binaria infantum. Между обратными явлениями приобретенного и врожденного сифилиса сушествует, однако, резкая разница. A. Диитриев.

\section{u) Невропатология.}

245. Лечение паркинсонизма банистерином и гармином. 1) К. В е$\mathrm{r}$ i $\mathrm{n}$ e r. 0 новом алколоиде, действующем на экстрапирамидную моторную систему. Nervenarzt 1928, № 5. 2) L e w in u. S c h u s ter. Результаты действия Banisterin'a на больных (D. m. W. 1928, 8 марта). 3) S-ch u ste r. Результаты опытов c Banisterin'om на нервных больных. (Med. Kl. 1929, 5 апр.). 4) B r ü c k l u. M u s zg u n g. Идентичность Harmin'a и Banisterin’a. (M.m.W. 1929, № 26) 5) R u s ti g e. Опыты с гармином. (D. m. W. 1929, 12 IV). Некоторые племена Южной Америки употребляют в качестве возбуждающего напитка настойку лианы Banisteria Caаpi. L e w in n Schuster за последнее время испытывали действие полученного пз этой лианы алколоида банистерина (формула $\mathrm{C}_{13} \mathrm{H}_{12} \mathrm{~N}_{2} \mathrm{O}$ ). Ввиду того, что этот алколоид вызывал двигательное возбуждение и мускульную легкость L e w i n испытал его в маленьких дозах 0,025 - 0,075 прежде всего на гемиплегиках; оказалось--движения значительно улучпились. Затем L e w in, B e r i n g e r и Sch u s te r пспытали банистерин на паркинсониках; под влиянием банистерина движения больных делались более легкими, быстрыми, регулярными, мимика делалась более выразительной, речь более быстрой, менее монотонной, останавливалось слюнотечение. Этот терапевтический эффект продолжался от 2 до 6 часов, затем постепенно ослабевал, но все же иногда давал себя знать несколько дней. Из 18 б-ных (8 послеэнцефалитич. паркинсоников, 7-болезнь Parkinson'a, 1 сл. паллидарная 
ригидность и 1 сл. СО-интоксикация), которым $\mathrm{S}$ ch u ster сделал 39 инъекций банистөрина, 12 б-ых получили улучшение. Дрожание остается без изменений. Бӓнистөрин, повидимому, средство исключительно противо-акинетическое. Несмотря на интерес опытов B eringer и S c h uster'a терапевтическое применение банистерина оставалось ограниченным, т. к. для приготовления 200 gr. банистерина требуется не менее $50 \mathrm{kgr}$ древесины Banisteriae Caаpi, а зона, где эта лиана растет, очень невелика и отдаленна. Но B r ü ckl и M us zg ung показали, что банистерин идентичен с гармином, добываемым из Peganum Harmala-травы, растущей в Туркестане, Сирии и северной Африке. Двигательно возбүждающее действие гармина известно давно, но не приходило мысли воспользоваться им для лечения паркинсоников. Теперь Stern, Fis c he r, Rus ti g e сообщают, что гармин в дозе 0,02 вызывает гакж улучпение двигательных явлений у паркинсоников. Rustig е лечил 18 пациентов: ригидность улучшилась у 6-ти лиц, причем у $3 \cdot \mathbf{x}$ почти исчезла; у 13 улучпились произвольные и автоматические движения, хотя действие гармина более скоропреходяще, чем банистерина. Во всяком случае опыты с банистерином и гармином заслуживают больпого внимания. Ю.

\section{Памати профессора Д. О. отта.}

(С портретом ${ }^{1}$ ).

В Ленинграде, 17-го июля с. г., скончался от uro-sepsis'a, на 75-м году жизни, известный ученый и выдающийся гинеколог напего Союза Д̆ м и т р и й Оскар о в и ч О т т. Этот талантливый человег, имя которого известно не только в СССР, но и за границей, умер на грани 50-летия своей научной, педагогической, врачебной и общественной делтельности. Характерными свойствами его личности являлсь-блестящий талант, огромная әрудиция, могучая энергия и исключительная работоспособность.

Д. О. О т т родилсл 11 февраля 1855 года в имении Плохино, Калужской губернии. В 1874 году он поступил в Медико-хирургическую (ныне Военно-недицинскую) академию. На младших курсах О т т интересовался теорстическими дисциплинами, особенно гистологией, ина 3-м курсе временно исполнял обязанности лаборанта по кафедре гистологии. Перейдя на старшие курсы, студент О т т, по разрепению проф. А. Я. $\mathrm{K}$ р а с о в с к о го, занимался в Петербургском Родовспомогательном доме. Будучи студентом 4-го курса, он выполнил в клинике проф. Славя н ского свою первую научную работу "О дренаже после лапаротомй“, удостоенную Конференцией Академии серебряной медали. В 1879 году Д. О. 0 т т окончил курс академии. В следующем за окончанием академии 1880/81 уч. году сдал экзамен на доктора медицины и на собственные средства отправился в заграничную командировку для дальнейшего научного усоверпенствования. Во время заграничной командировки, длившейся 3 года, молодой ученый посетил Париж, Лондон, Страсбэрг, Мюнхен, Дрезден, Прагу, Флоренцию, Вену, Иену, Галле, Берлин, Јейпциг. Находясь за границей, Д. О. свое внимание направил не только на изучение клинической части акушерства и гинекологии, но, что особенно важно, и теоретических их основ, причем значительную часть времени посвятил изучению физиологии.

Возвратившись из заграничной командировки, Д. О. предстагил в качестве диссертации на степень д-ра медицины работу под заглавием „0 влиянии на обескровленный организм вливания раствора поваренной соли и сравнение его действия с другими употребляемыми для трансфузии жидкостями“, и в апреле 1884 г. получил степень доктора медицины. В том же году он был избран приват-доцентом Академии.

Вскоре молодой приват-доцент получил два предложения: одно от проф. Heidenh a in'a- занять место адъюнкт профессора по кафедре физиологии в Бреславльском университете (Германия), другое от проф. П е л е х н а (Петербург) заведывать женским отделением руководимой им хирургической клиники. Желая посвятить себя клинической деятельности, Д. О. принял это второе предложение, после чего заведываемое им отделение в скором времени сделалось преимущественно гинекологическим. Осенью 1885 г. он был приглашен для препода-

1) Портрет относится к 1906 году. 